\title{
Isolation and molecular identification of the etiological agents of streptococcosis in Nile tilapia (Oreochromis niloticus) cultured in net cages in Lake Sentani, Papua, Indonesia
}

\author{
Hilal Anshary ${ }^{1 *}$, Rio A Kurniawan ${ }^{2}$, Sriwulan Sriwulan ${ }^{1}$, Ramli Ramli ${ }^{2}$ and Dolores V Baxa ${ }^{3}$
}

\begin{abstract}
Infections with Streptococcus spp. were observed in Nile tilapia cultured in net cages in Lake Sentani, Papua, Indonesia. Clinical signs included exophthalmia, erratic swimming, ascites in abdominal cavity, and external hemorrhages. Four types of bacterial colonies (SK, K10, P20, and M12) were isolated from the brain, kidney, and eyes. Based on phenotypic and genetic (16S rDNA sequencing) characteristics, the isolates were identified as Streptococcus iniae (SK), Streptococcus agalactiae (K10 and P20) and Lactococcus garvieae (M12). The latter species has not been previously isolated or reported from fish streptococcosis in Indonesia. Intraperitoneal injection of healthy tilapia with the bacterial species caused significant morbidity (70\%) within 3 days and 100\% mortality at 6 days post injection. Experimental infections and reisolation of the bacteria from morbid and dead fish suggest they are the causative agents of streptococcosis, which rendered high mortality among cage cultured Nile tilapia in Lake Sentani. Our results suggest the need for developing diagnostic tools for accurate identification of the agents of streptococcosis. As tilapia aquaculture continues to expand as a means of food production and livelihood in Indonesia, it becomes crucial to ensure that fish resources are monitored and protected from the adverse effects of infectious diseases.
\end{abstract}

Keywords: Streptococcosis; Nile tilapia; Cage; Lake Sentani; Streptococcus; Lactococcus garvieae

\section{Background}

Nile tilapia (Oreochromis niloticus) has been the focus of major aquaculture efforts worldwide because the fish is easy to cultivate, adapts to a wide range of environmental conditions, grows fast, tolerant to high stocking density, and is relatively resistant to stress and diseases (El-Sayed 2006). Nile tilapia is extensively cultivated in Indonesia particularly in Java, Sumatra, Kalimantan and Sulawesi Islands using various types of culture systems such as pond and net cage cultures in lakes or in dams (Working Group of Marine and Fisheries Data Arrangement 2013). Aquaculture of Nile tilapia in Indonesia has increased considerably from $291,030 \mathrm{MT}$ in 2008 to $695,063 \mathrm{MT}$ in

\footnotetext{
* Correspondence: hilalanshary@unhas.ac.id

'Laboratory of Fish Parasites and Diseases, Department of Fisheries, Faculty of Marine Science and Fisheries, Hasanuddin University, Makassar, Indonesia
} Full list of author information is available at the end of the article
2012 (Working Group of Marine and Fisheries Data Arrangement 2013), providing an important source of livelihood among communities along the shores of Lake Sentani, Papua, east Indonesia. Although commercial tilapia culture has been a profitable source of income for local fish farmers, infectious diseases have been emerging.

Streptococcosis, a bacterial disease, is one of the most significant diseases of tilapia worldwide. The causative agents of the disease have been attributed to multiple bacterial agents but most commonly Streptococcus and/ or Lactococcus (Kang et al. 2004; Plumb and Hanson 2011). Streptococcosis is a common disease affecting various species of fish worldwide (Roberts 2012) including the Asian seabass (Suanyuk et al. 2010), barramundi (Bromage et al. 1999), grouper (Bowater et al. 2012), Japanese flounder (Nguyen et al. 2002), rabbit fish (Yuasa et al. 1999), rainbow trout (Eldar and Ghittino 1999), red drum (Eldar et al. 1999; Shen et al. 2005), red tilapia 
(Hernandez et al. 2009; Musa et al. 2009), seabream (Evans et al. 2002), silver pomfret (Duremdez et al. 2004), and wild mullet (Evans et al. 2002). An annual global loss of about 250 million USD has been attributed to streptococcosis (Amal and Zamri-Saad 2011). The clinical signs of streptococcosis or lactococcosis include unilateral or bilateral exophthalmia, erratic swimming, pale gills, opaque cornea, external haemorrhages, enlarged spleen, ascites in abdominal cavities, and discolored liver (Suanyuk et al. 2005; Salati 2011).

Several species of Streptococcus and Lactococcus have been identified as the cause of streptococcosis/lactococcosis in fish including Streptococcus iniae, S. agalactiae (synonym S. difficile), S. dysgalactiae, S. parauberis, and Lactococcus garvieae (Eldar et al. 1994; Kang et al. 2004; Nomoto et al. 2004; Vendrell et al. 2006; Agnew and Barnes 2007; Soltani et al. 2008; Plumb and Hanson 2011; Abdelsalam et al. 2013). S. iniae and S. agalactiae have been frequently reported as the causative agents of streptococcosis in tilapia worldwide (Perera et al. 1994; Eldar et al. 1995; Bowser et al. 1998; Salvador et al. 2005; Suanyuk et al. 2005, 2010; Yuasa et al. 2008; Hernandez et al. 2009; Musa et al. 2009; Abuseliana et al. 2010; Lusiastuti et al. 2012; Najiah et al. 2012; Figueiredo et al. 2012). Except for one report from Brazil (Evans et al. 2009), L. garvieae has been rarely isolated in tilapia with streptococcosis. Enterococcus seriolicida, the synonym of L. garvieae (Eldar et al. 1996), is the most common causative agent of fish streptococcosis in Japan (Kusuda et al. 1991).

In Indonesia, S. agalactiae and S. iniae have been implicated in streptococcosis infections in commercial culture of tilapia (Yuasa et al. 2008; Lusiastuti et al. 2012). During a monitoring survey of the health status of tilapia in Lake Sentani from 2010 to 2013, severe morbidity and mortality were observed. Clinical symptoms included long white fecal string, erratic swimming, pale gills, opaque cornea, and exophthalmus. The isolated bacteria were $\beta$-haemolytic, Gram positive, non-motile cocci, and presumptively identified as Streptococcus sp. Biochemical testing failed to identify the bacteria to the species level. Despite the significant losses of tilapia due to streptococcal infection in Indonesia, few studies are available on the etiology of streptococcosis/lactococcosis in naturally infected fish. Furthermore, a more definitive identification of the causative agents using molecular techniques are currently lacking in Indonesia. For these reasons, the main goal of our study is to identify the causative agent(s) of streptococcosis among cage cultured tilapia in Lake Sentani, Papua, Indonesia using 16S rRNA gene sequencing and phylogenetic analysis. As a secondary objective, healthy tilapia were intraperitoneally inoculated with the bacterial isolates to confirm the etiology of the disease.

\section{Results}

Bacterial isolation and biochemical characterization

Moribund tilapia $(n=25)$ were observed at $1-4$ months following stocking in cages. Three types of Gram positive bacteria were isolated from the kidney (SK), brain (K10 and P20), and eyes (M12). Type strains were evaluated for biochemical characteristics and compared to $S$. iniae, S. agalactiae, and L. garvieae (Table 1). All isolates were cocci in chains, non-motile, catalase negative, oxidase negative, fermentative, and did not grow on MacConkey agar. The SK isolate was $\beta$-haemolytic while the rest were $\alpha$-haemolytic. Differences in biochemical tests among the three bacterial species were observed in esculin, salicin, trehalose, and Voges Proskauer tests. $S$. iniae and L. garvieae fermented esculin, lactose, salicin and trehalose, whereas $S$. agalactiae did not ferment the carbohydrates. L. garvieae was positive for lactose fermentation. S. iniae, in contrast to $S$. agalactiae and $L$. garvieae, showed a negative VP reaction. Except for mannitol utilization, K10 and P20 revealed similar biochemical characteristics with $S$. agalactiae described by Austin and Austin (2012). The SK isolate is similar to $S$. iniae in all biochemical characteristics. The M12 isolate was similar to L. garvieae except it utilized lactose but not sorbitol (Table 1).

\section{Pathogenicity of isolates}

The four isolates that were phenotypically similar to $S$. iniae (SK), S. agalactiae (K10 and P20), and L. garvieae (M12) showed high pathogenicity to tilapia. KaplanMeier survival analysis showed that the mean survival time of tilapia injected with $S$. iniae, S. agalactiae and $L$. garvieae $\left(0.1 \mathrm{ml}\right.$ of $\left.1.0 \times 10^{7} \mathrm{CFU} / \mathrm{mL}\right)$ was $2.5,1.83$, and 3 days, respectively (Figure 1 ). All of the fish injected with each suspension of the bacterial isolate showed clinical signs and died within 6 days after injection. Morbidity or mortality was not observed in the control group while the bacteria were recovered from morbid and dead fish in the exposed injected groups.

\section{Identification of the isolates by molecular methods}

The DNA of each isolate was analyzed by PCR using the 16S rRNA universal primers that amplified fragments of approximately $1,500 \mathrm{bp}$ in size. PCR reactions using these primers amplified a 1,482 bp from the SK isolate. Sequence alignments with known sequences in the GenBank database showed that the SK isolate had high similarity $(99.8-99.9 \%)$ to S. iniae from red drum in China, Nile tilapia in Thailand, $S$. iniae strain ATCC 29178 from Israel, rainbow trout in Iran, and S. iniae from Nile tilapia in Thailand (99.1\%). The 1,490 bp fragment from M12 showed a 100\% similarity with GenBank sequences of $L$. garvieae from yellowtail in Japan and from rainbow trout in Iran, $99.9 \%$ similarity with grey 
Table 1 Biochemical characteristics of bacterial isolates from Nile tilapia compared with Streptococcus iniae, S. agalactiae and Lactococcus garvieae

\begin{tabular}{|c|c|c|c|c|c|c|c|}
\hline \multirow[t]{2}{*}{ Characteristics } & \multirow{2}{*}{$\begin{array}{c}\text { S. iniae } \\
\text { (Austin and Austin 2012) }\end{array}$} & \multirow{2}{*}{$\begin{array}{c}\text { S. agalactiae } \\
\text { (Austin and Austin 2012) }\end{array}$} & \multirow{2}{*}{$\begin{array}{c}\text { L. garvieae } \\
\text { (Austin and Austin 2012) }\end{array}$} & \multicolumn{4}{|c|}{ Present Isolates } \\
\hline & & & & SK & P20 & K10 & M12 \\
\hline Gram stain & + & + & + & + & + & + & + \\
\hline Shape & Coccus & Coccus & Coccus & Coccus & Coccus & Coccus & Coccus \\
\hline Motility & - & - & - & - & - & - & - \\
\hline Aerobic growth & + & + & + & + & + & + & + \\
\hline Catalase & - & - & - & - & - & - & - \\
\hline Oxidase & - & - & - & - & - & - & - \\
\hline $\mathrm{O} / \mathrm{F}$ & $F$ & $\mathrm{~F}$ & $\mathrm{~F}$ & $\mathrm{~F}$ & $\mathrm{~F}$ & $\mathrm{~F}$ & $\mathrm{~F}$ \\
\hline Growth at $10^{\circ} \mathrm{C}$ & - & - & + & + & + & + & + \\
\hline Growth at $45^{\circ} \mathrm{C}$ & - & - & + & - & - & - & - \\
\hline Growth at $6.5 \% \mathrm{NaCl}$ & - & - & + & - & - & - & - \\
\hline Blood hemolysis & $\alpha / \beta$ & $-/ d$ & $a$ & $\beta$ & $a$ & $a$ & $a$ \\
\hline Esculin & + & - & + & + & - & - & + \\
\hline Lactose & - & - & - & - & - & - & + \\
\hline Mannitol & + & - & + & + & + & + & + \\
\hline Raffinose & - & - & - & - & - & - & - \\
\hline Salicin & + & - & + & + & - & - & + \\
\hline Sorbitol & - & - & + & - & - & - & - \\
\hline Trehalose & + & - & + & + & - & - & + \\
\hline VP test & - & + & + & - & + & + & + \\
\hline Glucose & + & + & + & + & + & + & + \\
\hline MacConkey Agar & - & - & - & - & - & - & - \\
\hline
\end{tabular}

mullet in Taiwan, 99.7\% with rainbow trout in Iran, and 99.4\% with giant freshwater prawn in Taiwan. The K10 $(1,487 \mathrm{bp})$ and P20 (1,491 bp) isolates showed a $99.8-$ 99.9\% sequence similarity to $S$. agalactiae from tilapia in China.

A phylogenetic tree was constructed using the Neighborjoining method which showed that $S$. agalactiae (K10 and P20) and S. iniae (SK) in the present study was placed in the same clade with respective species in GenBank (Figure 2). The same result was observed in the phylogenetic analysis of L. garvieae (M12) in that it was placed in the same clade as other L. garvieae reported from fish and shrimp (Figure 3).

\section{Discussion}

Streptococcosis is the main disease affecting Nile tilapia and many other fish species globally. Although the disease is widely distributed in Indonesia, particularly in West Java and South Sumatra Provinces, the nature and extent of the disease incidence in the region remain unclear. Previous studies showed that the causative agents of streptococcosis in Indonesia were identified as S. iniae using oligonucleotide probe array targeting a specific region in the $16 \mathrm{~S}$ rRNA (Yuasa et al. 2008) and $S$. agalactiae by multilocus sequence typing (Lusiastuti et al. 2012). The phenotypic characteristics of the present isolates SK, K10, P20, and M12 showed variable carbohydrate utilization when compared to S. iniae, $S$. agalactiae, and L. garvieae (Austin and Austin 2012). Other studies have shown that S. iniae, S. agalactiae, and L. garvieae isolated from different hosts have considerable diversity in biochemical characteristics including acid production from carbohydrates (Buller 2004; Cagirgan 2004; Garcia et al. 2008; Sharifiyazdi et al. 2010). Most S. agalactiae isolated from fish exhibited a negative reaction in mannitol test (Buller 2004; Garcia et al. 2008), but some strains from cattle showed a positive reaction (Garcia et al. 2008). Difference in lactose fermentation has been observed among L. garvieae strains. For example, L. garvieae from rainbow trout in Iran and L. garvieae ATCC 43921 as well as isolates from rainbow trout in Turkey were positive in lactose fermentation (Cagirgan 2004; Sharifiyazdi et al. 2010). As these studies demonstrate, differences in biochemical properties may provide important information on the physiological profile of the organism. However, phenotypic characteristics alone cannot provide a definitive identification to the species level. Molecular methods 


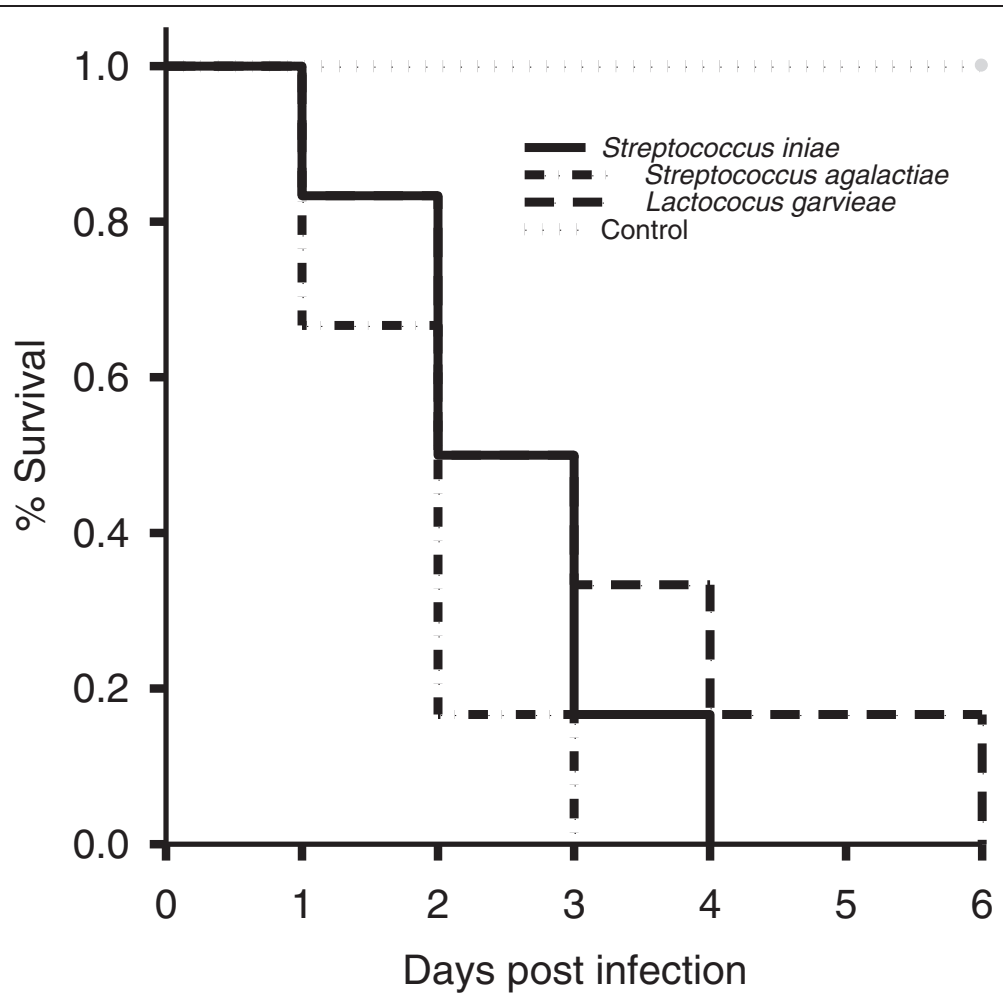

Figure 1 Kaplan-Meier survival curve of Nile tilapia after challenge with the isolates: Streptococcus iniae (SK), S. agalactiae (K10, P20) and Lactococcus garvieae (M12). Each fish was intraperitoneally injected with $0.1 \mathrm{ml}$ of each bacterial suspension $\left(1.0 \times 10^{7} \mathrm{CFU} / \mathrm{mL}\right.$ mean density).

have the ability to identify pathogenic species and to discriminate to species and strains level (Cunningham 2002) and were therefore used in the current study.

Based on phenotypic and gene sequence analyses, our study identified three species of bacteria (S. iniae, S. agalactiae, and L. garvieae) as the causative agents of streptococcosis/lactococcosis in the Nile tilapia reared in floating net cages in Lake Sentani, Papua. Sequencing the $16 \mathrm{~S}$ rRNA region and phylogenetic analysis showed high similarities (99.9 - 100\%) in nucleotide sequences between the current isolates as compared with specific sequences in GenBank. Based on these results, the isolates from the diseased tilapia in our study were confirmed as S. iniae (SK), S. agalactiae (K10 and P20) and L. garvieae (M12). There has been no previous report on the association and identification of L. garvieae in streptococcosis outbreaks in this region. To the best of our knowledge, our studies provide the first report on the isolation of $L$. garvieae among Nile tilapia in Indonesia suffering from streptococcosis. Globally, S. iniae and $S$. agalactiae are the most common agents of streptococcosis in tilapia with one report on L. garvieae from Brazil (Evans et al. 2009). Enterococcus seriolicida, the synonym of L. garvieae, is the agent of streptococcosis in yellowtail and eel culture in Japan (Kusuda et al. 1991). Although we have isolated three bacterial species (S. iniae,
S. agalactiae and L. garvieae) from cultured Nile tilapia, it is unknown if these pathogens co-existed in an individual fish. Streptococcosis in farm-raised Nile tilapia in Brazil showed S. agalactiae and S. difficile (Salvador et al. 2005) although the latter was eventually identified to be the same species as $S$. agalactiae based on whole cell protein profiles and high similarity in gene sequences (Vandamme et al. 1997; Kawamura et al. 2005). Infection with $S$. parauberis and $L$. garvieae have been reported from diseased flounder (Baeck et al. 2006) including mixed infection of S. iniae, S. dysgalactiae and L. garvieae in yellowtail (Hussein and Hatai 2006).

Koch's postulates confirmed S. iniae, S. agalactiae, and L. garvieae as the causative agents of streptococcosis among caged tilapia in Lake Sentani. Morbidity and mortality is predicted to be about $50-80 \%$ in cage cultured tilapia in the region. Small or larger fish (1 to 4 months post stocking) are apparently susceptible to the disease. Significant mortalities suggest that the seeded tilapia that was raised in hatcheries and then planted into the cages may have been the source of infection even if the fish succumbed to infection later. Although transmission of Streptococcus from wild to cultured fish is common (Zlotkin et al. 1998; Evans et al. 2002), the reservoir of infection with Streptococcus remains to be determined in Lake Sentani. Juvenile fish 


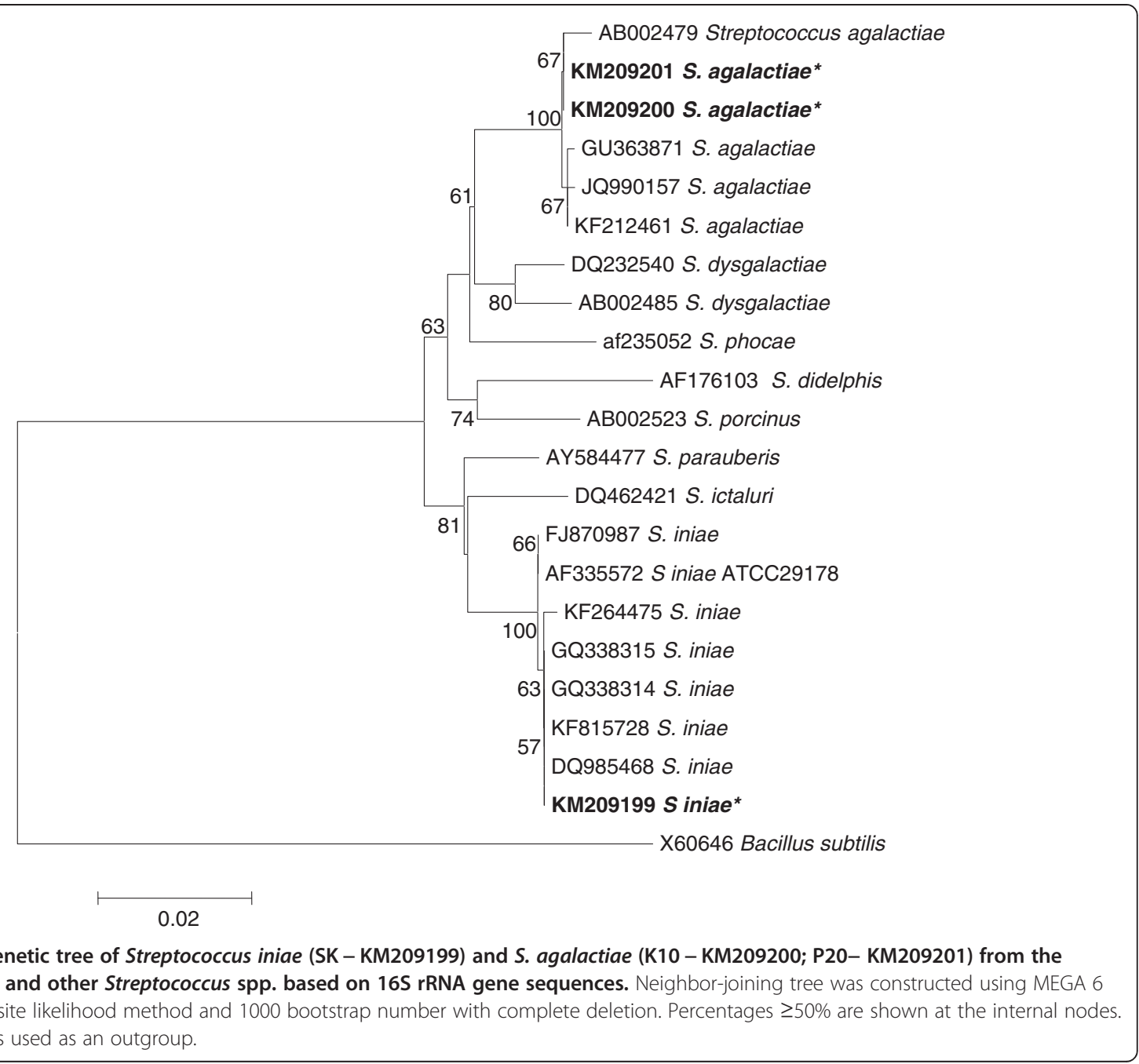

seeded into cages normally show signs of streptococcosis after 1 to 2 months of culture. It is unknown if the fish acquired the infection in the hatchery prior to seeding in the cages or were infected during cage culture where the disease progressed due to physicochemical stressors present in the lake. For example, mean water temperature at the time of sampling was $28.5^{\circ} \mathrm{C}$ in the morning and $30^{\circ} \mathrm{C}$ at noon. Previous studies suggest that high water temperature enhanced the severity of streptococcosis in cage cultured tilapia (Al-Marzouk et al. 2005; Baeck et al. 2006; Siti-Zahrah et al. 2008; Najiah et al. 2012). Dissolved oxygen, ammonia, turbidity, and $\mathrm{pH}$ also affected the progress of infections with $S$. agalactiae in cage culture of hybrid tilapia in lakes (Amal et al. 2013). Disease transmission among all life stages of fish are enhanced by environmental and internal factors (Schreck et al. 1993) and other risk factors such as water quality, pollutants, and fish management activities (Riley et al. 2008). Factors affecting the virulence of the bacteria isolated in the current study are unknown. In $S$. agalactiae, proteins and enzymes linked to cell surface metabolism were found while capsule genes, haemolysin and adhesion genes, were associated as virulence factors in L. garvieae (Morita et al. 2011; Miyauchi et al. 2012). Geographic strains also vary in pathogenicity as those observed in S. agalactiae (Evans et al. 2014).

Streptococcosis may be transmitted through various routes of infection. Infected fish release bacteria through the feces, survive in the water, and infect other healthy fish (Nguyen et al. 2002). S. iniae may be transmitted via oral and olfactory routes in the water column and enhance horizontal transmission of the bacteria (Shoemaker et al. 2000). In Lake Sentani, dead and moribund fish are immediately removed from healthy population. However, dead fish carcasses are recycled as food sources to cultivated species adjacent to the tilapia cage cultures. This practice provides a reservoir of infection to tilapia cultured in floating net cages and source of streptococcosis outbreaks across tilapia populations in the area. Feeding with contaminated diets is a source of streptococcosis outbreaks in 


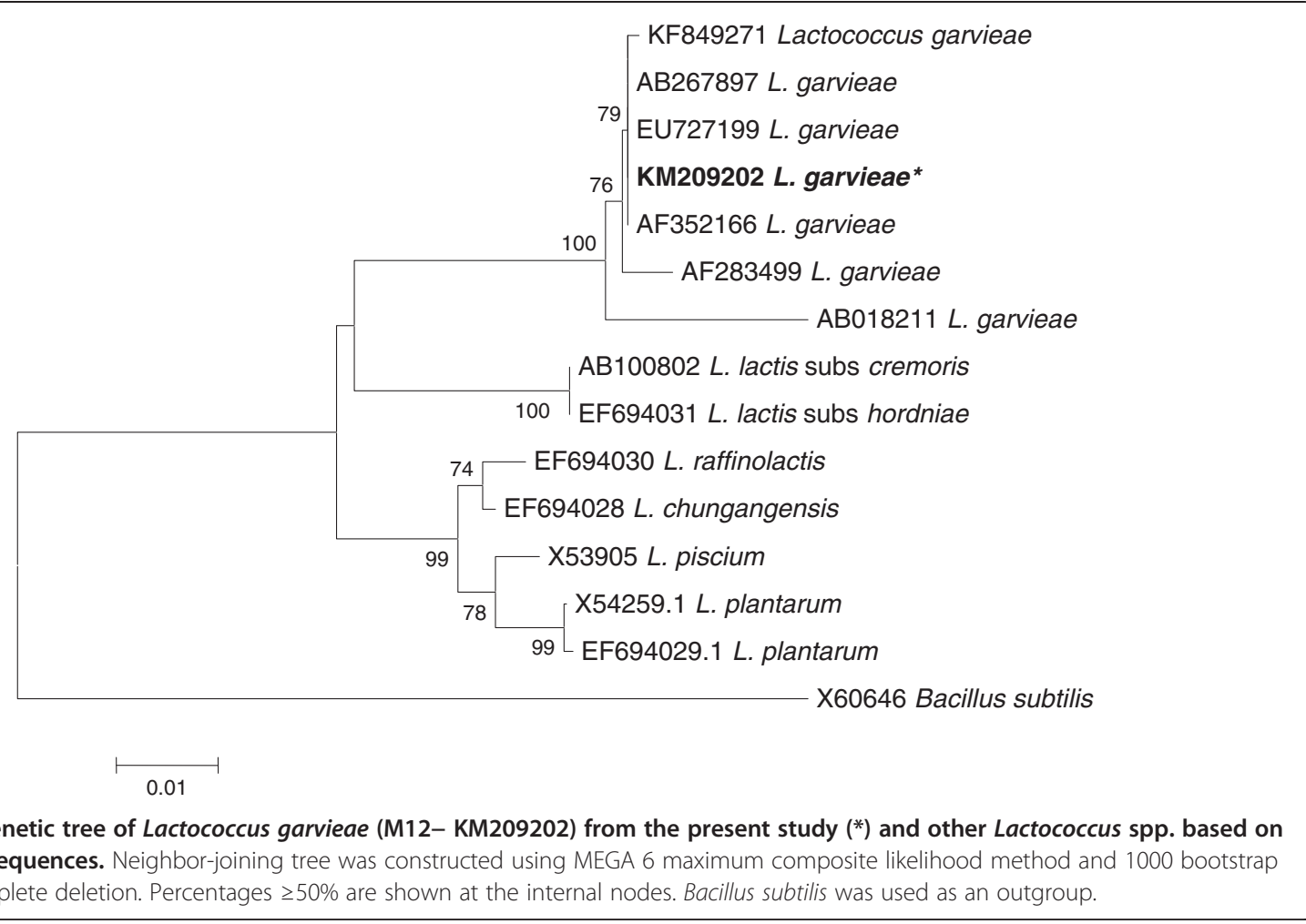

flounder in Korea (Kim et al. 2007). Transmission of bacteria from wild fish to cultured fish is also possible (Zlotkin et al. 1998; Evans et al. 2002). S. agalactiae isolated from diseased ya-fish (Schizothorax prenanti) could be experimentally transmitted to crucian carp (Carassius carassius) and Nile tilapia (Geng et al. 2012) suggesting potential horizontal transmission (e.g. fish to fish) among cultured species in the area. Since the bacteria have low host specificity, it is possible that the fish inhabiting the lake are carriers of the pathogen and subsequently act as reservoir of infection of tilapia cultivated in the lake. Together, these potential sources of infection may explain the persistence of streptococcosis among Nile tilapia cultured in Lake Sentani. Further study on the epidemiology of this disease in Lake Sentani may provide information on how to reduce the risks of streptococcosis outbreak in the region.

\section{Conclusions}

Based on phenotypic and genetic characteristics, three species were identified as the causative agents of streptococcosis in tilapia: S. iniae (SK), S. agalactiae (K10 and P20), and L. garvieae (M12). These species showed high pathogenicity in tilapia and were confirmed as the agents of streptococcosis by fulfilling Koch's postulates. All three species are the most likely cause of significant mortality in caged tilapia in Lake Sentani, Papua. The persistence of these pathogens in cultured tilapia and wild fish will be a bottleneck for intensive culture of tilapia in Lake Sentani. Developing standard and quantitative PCR assays using the specific gene sequences that we obtained in the current study will provide rapid and specific diagnostic techniques for early detection of the pathogen and for estimating the prevalence and distribution of fish infected with streptococcosis. The potential application of a vaccine is another promising area of investigation in the future to combat the spread of the disease. As tilapia aquaculture continues to expand as a means of food production in Indonesia, it becomes crucial to ensure that fish resources are protected from the adverse effects of diseases. Our results suggest the need for developing diagnostic tools to accurately identify the pathogens responsible for streptococcosis outbreaks. Monitoring hatchery and wild fish for the presence and severity of the disease will provide a better understanding for mitigating the impacts of streptococcosis.

\section{Methods}

\section{Isolation and identification of bacteria}

Tilapia $(n=25)$ with a total length of 15 to $25 \mathrm{~cm}$ and weight of 100 to $156 \mathrm{~g}$ with clinical signs including popeye/exophthalmia, pale gills, haemorrhage in eye, erratic and circular swimming were collected from floating net cages in Lake Sentani (Figure 4). The fish were put in three plastic bags containing water from the location and transported to the Laboratory of Molecular Biology, Fish Quarantine Inspection Agency (FQIA) Sentani, 


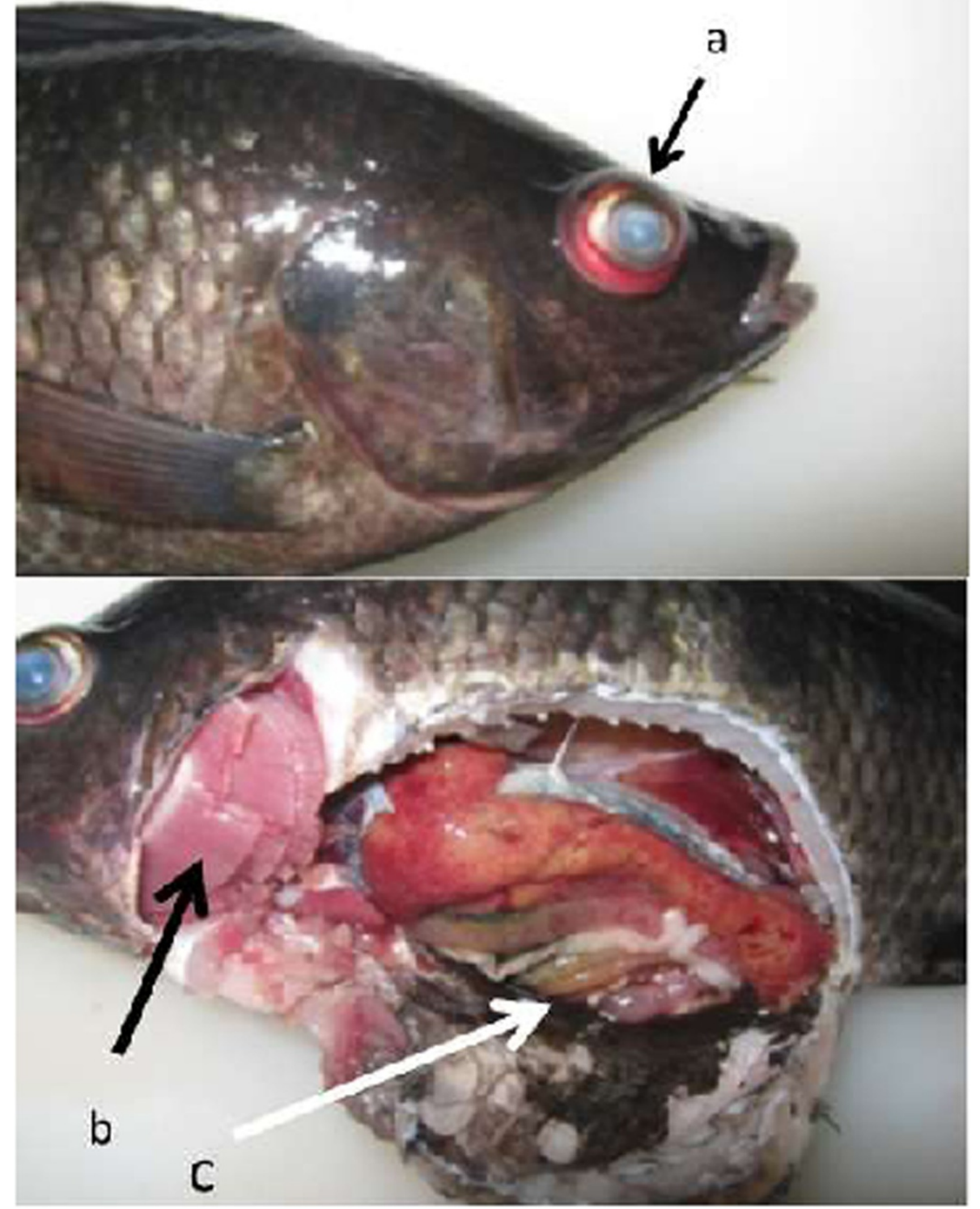

Figure 4 Nile tilapia (Oreochromis niloticus) from Lake Sentani showing gross clinical signs of streptococcosis. a) exophthalmus, opaque, and haemorrhagic eye, b) pale gill, and c) ascites in abdominal cavity.

Jayapura. The floating net cage is a unit from which 25 nets were suspended. Each net $(3 \times 3 \times 3 \mathrm{~m})$ was stocked with 1,000 juvenile tilapia $(15-25 \mathrm{~g})$, and deployed in the eastern part of Lake Sentani, Papua, Indonesia (Figure 5). The farmers purchased the tilapia seeds from a local hatchery and cultured in the cages from 3-4 months to reach a weight of about $170-$ $250 \mathrm{~g}$. Moribund fish are frequently observed within 1 to 2 months of culture. The average water temperature in the morning was $28.5^{\circ} \mathrm{C}$ at the time of sampling. In the current survey, tilapia showing clinical signs were collected at 1 to 4 months post stocking.
The fish were immediately examined in the laboratory for the presence of streptococcosis-causing bacteria. Bacteria were isolated aseptically from the kidney, brain, and eyes by streaking a loop onto Blood Agar and incubated at $35^{\circ} \mathrm{C}$ for 3 to 4 days. Most colonies that grew on the Blood Agar at 3 to 4 days post inoculation were small and whitish. Suspect bacterial colonies were sub-cultured onto Trypticase Soy Agar (TSA) and then subjected to morphological and biochemical tests. Colonies showing variation in biochemical tests, but were presumptively identified as Streptococcus according to Austin and Austin (2012), were subjected to PCR-sequencing in the $16 \mathrm{~S}$ rRNA region. 


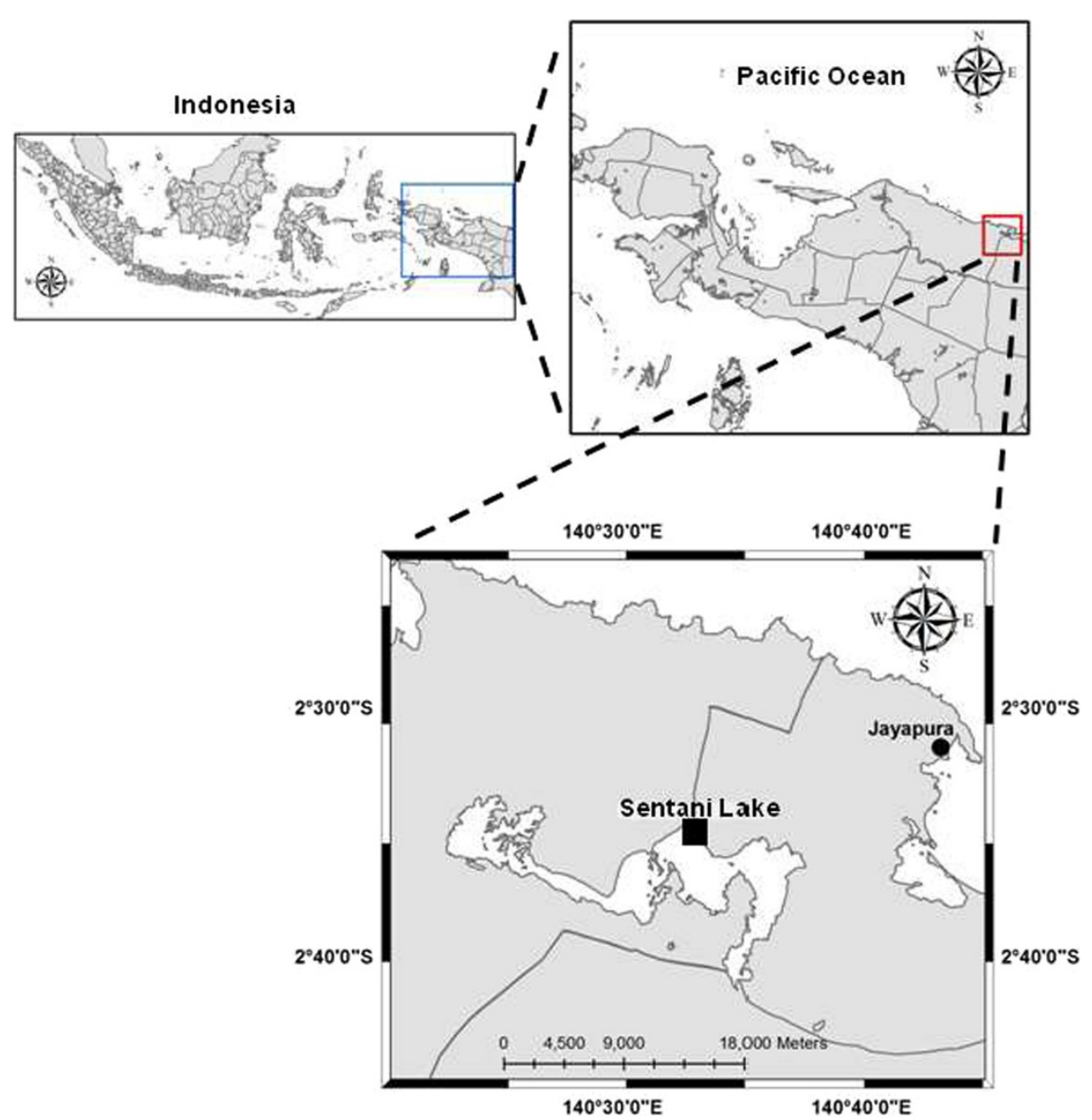

Figure 5 Map of Papua showing location of floating net cage in eastern Lake Sentani, Jayapura, Papua, Indonesia. Square mark indicates the sampling site.

\section{Pathogenicity test}

Pathogenicity test of the representative isolates (SK, K10, P20 and M12) was conducted using healthy tilapia (average weight $=100 \pm 2$ g). Groups of fish $(n=6 /$ tank $)$ were acclimatized in aquaria $(120 \times 30 \times 45 \mathrm{~cm})$ supplied with $120 \mathrm{l}$ freshwater and maintained at $35^{\circ} \mathrm{C}$ with aeration for about 2 weeks. The fish were fed with a commercial diet (PT Central Protein Prima) twice daily at a rate of $2 \%$ body weight. Water was $50 \%$ replaced and uneaten feed was siphoned daily. The bacteria were grown in Trypticase Soy Broth (TSB) overnight and the density of the bacterial suspension was enumerated using spread plate method on TSA. Each fish from the four groups was intraperitoneally injected with $0.1 \mathrm{ml}$ of the SK, K10, P20 and M12 bacterial suspension with a mean density of $1.0 \times 10^{7} \mathrm{CFU} / \mathrm{mL}$. A control group was included where fish were injected with the same volume of sterile phosphate buffered saline (PBS). Clinical signs and morbidity were recorded daily for one week and the experiment was terminated when 100\% morbidity or mortality occurred among the challenged groups. Newly dead or moribund fish were examined and tissues as described above were inoculated onto TSA. Colonies that grew on the plates were identified using biochemical tests to confirm the cause of morbidity or mortality. Kaplan-Meier survival analysis (Kaplan and Meier 1958) using SigmaPlot statistical analysis and graphing software program version 11.0 was conducted to determine the mean survival time of fish injected with suspensions of the bacterial isolates S. iniae, S. agalactiae and $L$. garvieae (SK, K10, P20 and M12).

\section{DNA extraction, PCR amplification and sequencing for $16 \mathrm{~S}$ rRNA}

The identity of the isolates was confirmed by $16 \mathrm{~S}$ rDNA sequencing. Pure colonies of SK, K10, P20 and M12 isolates were grown overnight in TSB medium at a concentration of $10^{9} \mathrm{CFU} / \mathrm{ml}$. One milliliter of each bacterial culture was transferred into a microcentrifuge tube and centrifuged at $7500 \mathrm{rpm}$ for $10 \mathrm{~min}$. The pellet was resuspended in $100 \mu \mathrm{L}$ buffer ATL and subjected to 
genomic DNA extraction following the protocols of the commercial kit (Qiagen, Gemany). The extracted gDNA was used to amplify the $16 \mathrm{~S}$ rRNA genes using the universal primer set for prokaryotes: Forward 24f 5'-AGAGTT TGATCCTGGCT-3', Reverse 1540r 5'-AAGGGAGGT GAT-CCAGCCGCA-3') (Friedrich 2002). The PCR assay $(20 \mu \mathrm{l})$ contained a final concentration of $10 \mathrm{x}$ buffer PCR, $0.5 \mathrm{mM}$ of each primer, $2.5 \mathrm{U} / \mu \mathrm{l}$ of HotStar Taq DNA polymerase, $2 \mu \mathrm{l}$ of DNA sample and nuclease free water was added to achieve the total volume of PCR mixture. The negative control utilized nuclease free water. Amplifications were carried out in a thermal cycler with an initial denaturation of $95^{\circ} \mathrm{C}$ for $5 \mathrm{~min}$, followed by 30 cycles of $92^{\circ} \mathrm{C}$ for $30 \mathrm{sec}, 52^{\circ} \mathrm{C}$ for $90 \mathrm{sec}, 72^{\circ} \mathrm{C}$ for $1 \mathrm{~min}$, and an additional final extension of $72^{\circ} \mathrm{C}$ for $5 \mathrm{~min}$. The expected PCR product of ca. 1,500 bp was detected by electrophoresis in $1.5 \%$ agarose stained with ethidium bromide and photographed under UV light.

The PCR products from isolate SK, K10, P20 and M12 were purified using the QIAquick PCR purification kit (Qiagen, Gemany) following the manufacturer's instructions and directly used in sequencing reaction. The purified PCR were sent to a commercial company (PT. Genetika Science Indonesia) for sequencing. Primers used for sequencing were the universal primers (24f and 1540r) as mentioned above. Additional internal primers including LF2 (AGGCAGCAGTAGGGAATC TT-3'), LF3 (5' -CTC TCTGGCCTGTAACTGAC-3'), SF2 (5'-GTGAGTGAA GAAGGT TTTCG-3'), SF3 (5'-CCATGTGTAGCGGTG AAATG-3'), and LacGarv (5'-TGGCCG ATCACCCTCT CAG-3') were designed using Primer3 software program and used in the sequencing to generate ca. 1,500 bp nucleotide sequences. The PCR products from K10, P20, and M12 isolates were sequenced in both direction using the primers $24 \mathrm{f}$ and 1540r, and the internal primers LF2, LF3, and LacGarv. The SK isolates was sequenced using the primers $24 \mathrm{f}$ and 1540r and the internal primers SF2, SF3, and LacGarv.

\section{Phylogenetic analysis}

The 16S rRNA gene sequences obtained from the four isolates were aligned with Streptococcus spp. and Lactococcus spp. from GenBank database using Clustal X software version 2.1. A phylogenetic analysis was performed using MEGA 6 software (Tamura et al. 2013). Neighbor-joining tree was constructed for both Streptococcus spp. and Lactococcus spp. using Bacillus subtilis as an out group. Gene sequences for SK, K10, P20 and M12 were deposited in GenBank under accession numbers KM209199, KM209200, KM209201 and KM209202, respectively.

\section{Competing interests}

The authors declare that they have no competing interests.

\section{Authors' contributions}

HA, RAK, and SS designed and conducted the molecular part of the study including the phylogenetic analyses. RR and RAK collected samples, conducted biochemical tests and challenge experiment. HA and DVB interpreted the findings and wrote the paper. All authors helped to prepare the manuscript and all approved the final manuscript revision.

\section{Acknowledgements}

This research was supported by the Fish Quarantine Inspection Agency, Sentani, Jayapura and Hasanuddin University. We thank Prof. Susan L. Williams (Bodega Marine Laboratory, University of California) for her critical reading of this manuscript. Thanks also to Ir. Anwar, the previous head of FQIA, for his excellent support during the study, and all members of the Fish Quarantine Sentani, Papua for their good cooperation. The University of California, Davis Outreach and International Programs Seed Grant is acknowledged for partial funding support to DVB for initiating collaborations with Hasanuddin University and this study.

\section{Author details}

${ }^{1}$ Laboratory of Fish Parasites and Diseases, Department of Fisheries, Faculty of Marine Science and Fisheries, Hasanuddin University, Makassar, Indonesia. ${ }^{2}$ Fish Quarantine and Inspection Agency Regional Jayapura, Ministry of Marine Affairs and Fisheries, Jakarta, Republic of Indonesia. ${ }^{3}$ School of Veterinary Medicine, Department of Anatomy, Physiology, and Cell Biology, University of California, Davis, CA 95616, USA.

Received: 25 July 2014 Accepted: 7 October 2014

Published: 24 October 2014

\section{References}

Abdelsalam M, Asheg A, Eissa AE (2013) Streptococcus dysgalactiae: An emerging pathogen of fishes and mammals. Int J Vet Sci Med 1:1-6

Abuseliana A, Daud H, Aziz SA, Bejo SK, Alsaid M (2010) Streptococcus agalactiae the etiological agent of mass mortality in farmed red tilapia (Oreochromis sp.). J Anim Vet Adv 9(20):2640-2646

Agnew W, Barnes AC (2007) Streptococcus iniae: an aquatic pathogen of global veterinary significance and a challenging candidate for reliable vaccination. Vet Microbiol 122:1-15

Al-Marzouk A, Duremdez R, Yuasa K, Sameer AZ, Al-Gharabally H, Munday B (2005) Fish Kill of Mullet Liza klunzingeri in Kuwait Bay: The Role of Streptococcus agalactiae and the Influence of Temperature. In: Walker P, Lester R, BondadReantaso MG (ed) Diseases in Asian Aquaculture V. Fish Health Section, Asian Fisheries Society, Manila

Amal MNA, Zamri-Saad M (2011) Streptococcosis in tilapia (Oreochromis niloticus): a review. Pertanika J Trop Agric Sci 34:195-206

Amal MNA, Zamri-Saad M, Zahrah AS, Zulkafli AR (2013) Water quality influences the presence of Streptococcus agalactiae in cage cultured red hybrid tilapia. Oreochromis niloticus X Oreochromis mossambicus. Aquac Res doi:10.1111/ are. 12180

Austin B, Austin DA (2012) Bacterial Fish Pathogens: Disease of Farmed and Wild Fish, 5th edition. Springer Science and Business Media Dordrecht, London

Baeck GW, Kim JH, Gome DK, Park SC (2006) Isolation and characterization of Streptococcus sp. from diseased flounder (Paralichthys olivaceus) in Jeju Island. J Vet Sci 7:53-58

Bowater RO, Forbes-Faulkner J, Anderson IG, Condon K, Robinson B, Kong F, Gilbert GL, Reynolds A, Hyland S, McPherson G, Brien JO, Blyde D (2012) Natural outbreak of Streptococcus agalactiae (GBS) infection in wild giant Queensland grouper, Epinephelus lanceolatus (Bloch), and other wild fish in northern Queensland, Australia. J Fish Dis 35:173-186

Bowser PR, Wooster GA, Getchell RG, Timmons MB (1998) S. iniae infection of tilapia $O$. niloticus in a recirculation production facility. J World Aquacult Soc 29:335-339

Bromage ES, Thomas A, Owens L (1999) Streptococcus iniae a bacterial infection in barramundi Lates calcarifer. Dis Aquat Org 36:177-181

Buller NB (2004) Bacteria From Fish and Other Aquatic Animals: A Practical Identification Manual. CABI Publishing, Cambridge

Cagirgan H (2004) Biotyping of Lactococcus garvieae isolated from Turkey. J Fish Aquat Sci 21:267-269

Cunningham CO (2002) Molecular diagnosis of fish and shellfish diseases: present status and potential use in disease control. Aquaculture 206:19-55 
Duremdez R, Al-Marzouk A, Qasem JA, Al-Harbi A, Gharabally H (2004) Isolation of Streptococcus agalactiae from cultured silver pomfret, Pampus argenteus (Euphrasen) in Kuwait. J Fish Dis 27:307-310

Eldar A, Ghittino C (1999) Lactococcus garvieae and Streptococcus iniae infections in rainbow trout, Oncorhynchus mykiss: similar but different diseases. Dis Aquat Org 36:227-231

Eldar A, Bejerano Y, Bercovier H (1994) Streptococcus shiloi and Streptococcus difficile, two new streptococcal species causing a meningoecephalitis in fish. Curr Microbiol 28:139-143

Eldar A, Frelier PF, Assenta L, Varner PW, Lawhon S, Bercovier H (1995) Streptococcus shiloi, the name for an agent causing septicemic infection in fish, is a junior synonym of Streptococcus iniae. Int J Syst Bacteriol 45:840-842

Eldar A, Ghittino C, Asanta L, Bozzetta E, Goria M, Prearo M, Bercovier H (1996) Enterococcus seriolicida is a junior synonym of Lactococcus garvieae, a causative agent of septicemia and meningoencephalitis in fish. Curr Microbiol 33:85-88

Eldar A, Perl S, Frelier PF, Bercovier H (1999) Red drum Sciaenops ocellatus mortalities associated with Streptococcus iniae infection. Dis Aquat Org 36:121-127

El-Sayed AFM (2006) Tilapia Culture. CABI Publishing, Oxfordshire, UK

Evans JJ, Klesius PH, Gilbert PM, Shoemaker CA, Al-Sarawi MA, Landsberg J, Duremdez R, Al Marzouk A, Al Zenki S (2002) Characterization of B-haemolytic group B Streptococcus agalactiae in cultured seabream, Sparus auratus L. and wild mullet, Liza klunzingeri (Day) in Kuwait. J Fish Dis 25:505-513

Evans JJ, Klesius PH, Shoemaker CA (2009) First isolation and characterization of Lactococcus garvieae from Brazilian Nile tilapia, Oreochromis niloticus (L.) and pintado, Pseudoplathystoma corruscans (Spix \& Agassiz). J Fish Dis 32:943-951

Evans JJ, Pasnik DJ, Klesius PH (2014) Differential pathogenicity of five Streptococcus agalactiae isolates of diverse geographic origin in Nile tilapia (Oreochromis niloticus L.). Aquac Res doi:10.1111/are.12393

Figueiredo HCP, Netto LN, Leal CAG, Pereira UP, Mian GF (2012) Streptococcus iniae outbreaks in Brazilian Nile tilapia (Oreochromis niloticus L.) farms. Braz J Microbiol 43(2):576-580

Friedrich MW (2002) Phylogenetic analysis reveals multiple lateral transfers of adenosine-5-phosphosulfate reductase genes among sulfate-reducing microorganisms. J Bacteriol 184(1):278-289

Garcia JC, Klesius PH, Evans JJ, Shoemaker CA (2008) Non-infectivity of cattle Streptococcus agalactiae in Nile tilapia, Oreochromis niloticus and channel catfish, Ictalurus punctatus. Aquaculture 281:151-154

Geng Y, Wang KY, Huang XL, Chen DF, Li CW, Ren SY, Liao YT, Zhou ZY, Liu QF, Du ZJ, Lai WM (2012) Streptococcus agalactiae, an emerging pathogen for cultured Ya-Fish, Schizothorax prenanti, in China. Transbound Emerg Dis 59:369-375

Hernandez E, Figueroa J, Iregui C (2009) Streptococcosis on a red tilapia. Oreochromis sp. farm: A case study. J Fish Dis 32:247-252

Hussein MMA, Hatai K (2006) Multiplex PCR for detection of Lactococcus garvieae, Streptococcus iniae and S. dysgalactiae in cultured yellowtail. Aquacult Sci 54:269-274

Kang SH, Shin GW, Shin YS, Palaksha KJ, Kim YR, Yang HH, Lee EY, Lee EG, Huh $\mathrm{NE}$, Ju OM, Jung TS (2004) Experimental evaluation of pathogenicity of Lactococcus garvieae in black rockfish (Sebastes schlegeli). J Vet Sci 5:387-390

Kaplan EL, Meier P (1958) Nonparametric estimation from incomplete observations. J Am Stat Assoc 53:457-481

Kawamura Y, Itoh Y, Mishima N, Ohkusu K, Kasai H, Ezaki T (2005) High genetic similarity of Streptococcus agalactiae and Streptococcus difficilis: S. difficilis Eldar et al. 1995 is a later synonym of S. agalactiae Lehmann and Neumann 1896 (Approved Lists 1980). Int J Syst Evol Microbiol 55:961-965

Kim JH, Gomez DK, Choresca CH, Park SC (2007) Detection of major bacterial and viral pathogens in trash fish used to feed cultured flounder in Korea. Aquaculture 272:105-110

Kusuda R, Kawai K, Salati F, Banner CR, Fryer JL (1991) Enterococcus seriolicida sp. Nov., a fish pathogen. Int J Syst Bacteriol 41:406-409

Lusiastuti AM, Textor M, Seeger H, Akineden O, Zschock M (2012) The occurrence of Streptococcus agalactiae sequence type 261 from fish disease outbreaks of tilapia Oreochromis niloticus in Indonesia. Aquac Res 1-4. doi:10.1111/ are.12069

Miyauchi E, Toh H, Nakano A, Tanabe S, Morita H (2012) Comparative genomic analysis of Lactococcus garvieae strains isolated from different sources reveals candidate virulence genes. Int J Microbiol doi:10.1155/2012/728276

Morita H, Toh H, Oshima K, Yoshizaki M, Kawanishi M, Nakaya K, Suzuki T, Miyauchi E, Ishii Y, Tanabe S, Murakami M, Hattori M (2011) Complete genome sequence and comparative analysis of the fish pathogen Lactococcus garvieae. PLoS One 6(8):e23184. doi:10.1371/journal. pone.0023184

Musa N, Wei LS, Musa N, Hamdan RH, Leong LK, Wee W, Amal MN, Kutty BM, Abdullah SZ (2009) Streptococcosis in red hybrid tilapia (Oreochromis niloticus) commercial farms in Malaysia. Aquac Res 40:630-32

Najiah M, Aqilah NI, Lee KL, Khairulbariyyah Z, Mithun S, Jalal KCA, ShaharomHarrison F, Nadirah M (2012) Massive mortality associated with Streptococcus agalactiae infection in cage-cultured red hybrid tilapia Oreochromis niloticus in Como River, Kenyir Lake, Malaysia. J Biol Sci 12:438-442

Nguyen HT, Kanai K, Yoshikoshi K (2002) Ecological investigation of S. iniae isolated in cultured Japanese Flounder, Paralicthys olivaceus using selective isolation procedure. Aquaculture 205:7-17

Nomoto R, Munasinghe LI, Jin DH, Shimahara Y, Yasuda H, Nakamura A, Misawa N, Itami T, Yoshida T (2004) Lancefield group C Streptococcus dysgalactiae infection responsible for fish mortalities in Japan. J Fish Dis 27:679-686

Perera RP, Johnson SK, Collins MD, Lewis DH (1994) Streptococcus iniae associated with mortality of Tilapia nilotica $\times T$. aurea hybrids. J Aquat Anim Health 6:335-340

Plumb JA, Hanson LA (2011) Health Maintenance and Principal: Microbial Diseases of Cultured Fishes, 3rd edition. Wiley-Blackwell, lowa, USA

Riley SC, Munkittrick KR, Evans AN, Krueger CC (2008) Understanding the ecology of disease in Great Lakes fish populations. Aquat Ecosys Health Manag 11:321-334

Roberts RJ (2012) The Bacteriology of Teleosts. In: Roberts RJ (ed) Fish Pathology, 4th edition. John Wiley and Sons, UK

Salati F (2011) Enterococcus seriolicida and Streptococcus spp. (S. iniae, S. agalactiae and S. dysgalactiae). In: Woo PTK, Bruno DW (ed) Fish Diseases and Disorders. Viral, Bacterial and Fungal Infections, Vol 3. CAB International, Oxfordshire, pp 375-396

Salvador R, Muller EE, Freitas JC, Leonhadt JH, Giordano LGP, Dias JA (2005) Isolation and characterization of Streptococcus spp. group B in Nile tilapia (Oreochromis niloticus) reared in hapas nets and earth nurseries in the northern region of Parana State, Brazil. Cienc Rural 35:1374-1378

Schreck CB, Maule AG, Kaattari SL (1993) Stress and Disease Resistance. In: Muir JF, Roberts RJ (ed) Recent Advances in Aquaculture, vol 4. Blackwell Scientific Publishing, Oxford, UK, pp 170-175

Sharifiyazdi H, Akhlaghi M, Tabatabaei M, Mostafavi Zadeh SM (2010) Isolation and characterization of Lactococcus garvieae from diseased rainbow trout (Oncorhynchus mykiss, Walbaum) cultured in Iran. Iran J Vet Res 11:342-350

Shen ZH, Qian D, Xiu WJ, Gu JH, Shao JZ (2005) Isolation, identification and pathogenicity of Streptococcus iniae isolated from red drum Sciaenops ocellatus. Acta Hydrobiol Sin 29:678-683

Shoemaker CA, Evans JJ, Klesius PH (2000) Density and dose: factors affecting mortality of Streptococcus iniae infected tilapia, Oreochromis niloticus. Aquaculture 188:229-235

Siti-Zahrah A, Padilah B, Azila A, Rimatulhana R, Shahidan H (2008) Multiple Streptococcal Species Infection in Cage-Cultured Red Tilapia But Showing Similar Clinical Signs. In: Bondad-Reantaso MG, Mohan CV, Crumlish M, Subasinghe RP (ed) Diseases in Asian Aquaculture VI. Fish Health Section, Asian Fisheries Society, Manila

Soltani M, Nikbakht G, Ebrahimzadeh Moussavi HA, Ahmadzadeh N (2008) Epizootic outbreaks of Lactococcosis caused by Lactoccoccus garvieae in farmed rainbow trout (Onchorhynchus mykiss) in Iran. B Eur Assoc Fish Pat 28:95-106

Suanyuk N, Kangheae H, Khongpradit R, Supamattaya K (2005) Streptococcus agalactiae infection in tilapia (Oreochromis niloticus). Songklanakarin J Sci Technol 27:307-319

Suanyuk N, Sukkasame N, Tanmark N, Yoshida T, Itami T, Thune RL, Tantikitti C, Supamattaya K (2010) Streptococcus iniae infection in cultured Asian seabass (Lates calcarifer) and red tilapia (Oreochromis sp.) in southern Thailand. Songklanakarin J Sci Technol 32:341-348

Tamura K, Stecher G, Peterson D, Filipski A, Kumar S (2013) MEGA6: Molecular evolutionary genetics analysis version 6.0. Mol Biol Evol 30:2725-2729

Vandamme P, Devriese LA, Pot B, Kersters K, Melin P (1997) Streptococcus difficile is a nonhemolytic group B, type Ib Streptococcus. Int J Syst Bacteriol 47:81-85

Vendrell D, Balcazar JL, Ruiz-Zarzuela I, de Blas I, Girones O, Muzquiz JL (2006) Lactococcus garvieae in fish: a review. Comp Immunol Microbiol Infect Dis 29:177-198

Working Group of Marine and Fisheries Data Arrangement (2013) Marine and fisheries in figures 2013. Center for data statistics and information. Ministry of Marine Affair and Fisheries of Indonesia, Indonesia 
Yuasa K, Kitancharoen N, Yasuoka K, Faisal AA (1999) Streptococcus iniae, the causative agent of mass mortality in rabbitfish Siganus canaliculatus in Bahrain. J Aquat Anim Health 11:87-93

Yuasa K, Kamaishi T, Hatai K, Bahnnan M, Borisutpeth P (2008) Two Cases of Streptococcal Infections of Cultured Tilapia In Asia. In: Bondad-Reantaso MG, Mohan CV, Crumlish M, Subasinghe RP (ed) Diseases in Asian Aquaculture VI. Fish Health Section, Asian Fisheries Society, Manila

Zlotkin A, Hershko H, Eldar A (1998) Possible transmission of Streptococcus iniae from wild fish to cultured marine fish. Appl Environ Microbiol 64:4065-4067

doi:10.1186/2193-1801-3-627

Cite this article as: Anshary et al:: Isolation and molecular identification of the etiological agents of streptococcosis in Nile tilapia (Oreochromis niloticus) cultured in net cages in Lake Sentani, Papua, Indonesia.

SpringerPlus 2014 3:627.

\section{Submit your manuscript to a SpringerOpen ${ }^{\circ}$} journal and benefit from:

- Convenient online submission

- Rigorous peer review

- Immediate publication on acceptance

- Open access: articles freely available online

- High visibility within the field

- Retaining the copyright to your article

Submit your next manuscript at $>$ springeropen.com 